(A) Check for updates

Cite this: Food Funct., 2018, 9, 5621

\section{Bioactive properties and phytochemical assessment of Bacupari-anão (Garcinia brasiliensis Mart.) leaves native to Rondônia, Brazil}

\author{
Renato André Zan, $\dagger^{\mathrm{a}, \mathrm{b}}$ Ângela Fernandes, (D) $\dagger^{\mathrm{c}}$ Stephanie Jedoz, ${ }^{\mathrm{a}, \mathrm{c}}$ \\ Taofiq Oludemi, (D) c Ricardo C. Calhelha, (D) c Tânia C. S. P. Pires, (DD c \\ Maria José Alves, (iD c Roberto Carlos Campos Martins, iD b Lillian Barros (iD *c and \\ Isabel C. F. R. Ferreira (iD *c
}

\begin{abstract}
Leaf fractions of Garcinia brasiliensis were evaluated concerning their antioxidant, antimicrobial, antiinflammatory and cytotoxic properties, and the most active fraction was then fully characterized regarding its phenolic composition using HPLC-DAD-ESI/MSn. The ethyl acetate fraction from partitioning of the methanolic leaf extract revealed a strong antioxidant activity that was comparable to Trolox, the positive control. This fraction was also able to show a significant antimicrobial activity against Gram-positive and Gram-negative bacteria and the fungus Candida albicans. However, the dichloromethane fraction was found to present the highest anti-inflammatory $\left(83 \pm 9 \mu \mathrm{g} \mathrm{mL} \mathrm{L}^{-1}\right)$ and cytotoxic activities, thus presenting slight toxicity using a non-tumor cell line. Regarding the phenolic profile, the ethyl acetate fraction presented twelve flavonoids, with morelloflavone-7"-O-glucoside $\left(52.1 \pm 0.4 \mathrm{mg} \mathrm{g}^{-1}\right)$ and gardinia biflavonoid 2 a glucoside $\left(27.5 \pm 0.2 \mathrm{mg} \mathrm{g}^{-1}\right)$ being the major compounds identified. These results indicate that leaves of $G$. brasiliensis might be a potential source of natural biomolecules for pharmaceutical and medicinal applications
\end{abstract}

Received 22nd July 2018, Accepted 27th August 2018

DOI: $10.1039 /$ c8fo01474d

rsc.li/food-function medicinal plants have been recognized as an alternative medicine since ancient times. ${ }^{3}$

The Amazon rainforest is present in nine countries of South America (Brazil, Peru, Colombia, Venezuela, Ecuador, Bolivia, Guyana, Suriname and French Guiana) with 60\% present in the Brazilian territory. ${ }^{4}$ Ethnopharmacological fieldstudies have identified several medicinal species popularly used for the treatment of a wide range of diseases. Despite the rich biodiversity of this region, there is still a lack of comprehensive studies regarding the uses, bioactivities, chemical composition and pharmacological properties of many of these medicinal plants.

The genus Garcinia belongs to the family of Guttiferae (Clusiaceae) and it is one of the genera found in some parts of the Amazon forest. This genus includes more than 1000 species whose plant parts (fruits, flowers, leaves, barks and stems) have attracted a lot of attention because of their secondary metabolite composition, being used globally in traditional medicine to treat disorders such as inflammation, microbial infections, and cancer. ${ }^{5,6}$ An increasing number of researchers are interested in bioactive compounds extracted from Garcinia species, due to their large use in folk medicine. ${ }^{7,8}$

Garcinia brasiliensis Mart. is a green plant native to the Amazon region, cultivated for its edible fruit, popularly 
referred to as Bacupari-anão or guapomo, in Brazil and Ecuador, respectively. ${ }^{9,10}$ Some of its bioactive properties are well reported, including antioxidant, ${ }^{9}$ antidiabetic, ${ }^{10}$ antiinflammatory, ${ }^{11}$ antispasmodic, ${ }^{7}$ in vivo photoprotective, ${ }^{12}$ and antiprotozoal activities. ${ }^{13}$ The leaves of $G$. brasiliensis have also been used in Brazilian folk medicine for the treatment of tumors, to suppress the pain associated with arthritis, and for other inflammatory disorders. ${ }^{14}$ However, very little work has been published regarding their phytochemical profiling and the compounds-bioactivity relationship of extracts from its vegetative organs.

In view of these pharmaceutical potentials, leaves of G. brasiliensis were subjected to a cold methanol extraction and further liquid-liquid partitioning to obtain hexane, dichloromethane and ethyl acetate fractions. All fractions were then tested in search of their antioxidant, anti-inflammatory, antimicrobial and cytotoxic activities. Furthermore, the phenolic composition of the most bioactive extract was analyzed using HPLC-DAD-ESI/MSn.

\section{Materials and methods}

\subsection{Collection of plant materials}

Leaves of $G$. brasiliensis were collected at the São Cristóvão site, located in Lot 11A1, Gleba G, Sector 04, in Presidente Médici, RO, in September 2017. Identification of the species was carried out through the evaluation of its botanical characteristics and comparing with those previously reported in literature by the Botanist Master Joseane Bessa Barbosa. A voucher specimen was deposited at the Antônio Dalla Martha Herbarium of the Lutheran University Center of Ji-Paraná (CEULJI/ULBRA) under number 317. The plant material was subjected to drying in an oven at $40{ }^{\circ} \mathrm{C}$ for seven days and then crushed in a knife-type mill.

\subsection{Preparation of crude alcoholic extract and liquid-liquid partitioning}

Part of the dried and crushed leaves (100 g) of G. brasiliensis were extracted in cold methanol by exhaustive percolation. Subsequently, the solvent was evaporated in a rotatory evaporator (Büchi R-210, Flawil, Switzerland) under vacuum and lyophilized (FreeZone 4.5, Labconco, Kansas City, MO, USA), yielding a methanolic extract $(11.5 \mathrm{~g})$. This extract was then subjected to liquid-liquid partitioning, by re-dissolving the extract in methanol/water $(30: 70)$ and then extracting it with hexane, dichloromethane and ethyl acetate, yielding the hexane (264.6 $\mathrm{mg})$, dichloromethane $(916.6 \mathrm{mg}$ ) and ethyl acetate $(496.9 \mathrm{mg})$ fractions.

\subsection{Evaluation of bioactive properties}

2.3.1. Antioxidant activity. Four different assays were used to assess the in vitro antioxidant potential of each fraction: scavenging effects on DPPH (2,2-diphenyl-1-picrylhydrazyl radicals (RSA), reducing power measured by ferricyanide Prussian blue assay (RP), $\beta$-carotene bleaching inhibition (CBI) and lipid peroxidation inhibition (LPI) by thiobarbituric acid reactive substances (TBARS) assay, following a procedure previously described by Petropoulos et $a .^{15}$ All the results obtained were expressed as $\mathrm{EC}_{50}$ values, corresponding to the extract concentration that provides $50 \%$ of antioxidant activity, or 0.5 of absorbance in the case of a reducing power assay. Trolox (6-hydroxy-2,5,7,8-tetramethylchroman 2-carboxylic acid, Sigma-Aldrich, St Louis, MO, USA) was used as a positive control.

2.3.2. Anti-inflammatory activity. To assess the anti-inflammatory activity, a macrophage-like cell line, RAW 264.7, was used and cultured following a procedure previously described by Taofiq et al. ${ }^{16}$ The nitrite levels produced were determined by measuring the optical density at $515 \mathrm{~nm}$ using a microplate reader, and the obtained results were compared with the standard calibration curve. Dexamethasone $(50 \mu \mathrm{M})$ was used as the positive control. The results were expressed in $\mathrm{EC}_{50}$ values, corresponding to the extract concentration that inhibited $50 \%$ of NO production.

2.3.3. Cytotoxic activity. The cytotoxicity was evaluated using four tumor cell lines, HeLa (cervical carcinoma), HepG2 (hepatocellular carcinoma), MCF-7 (breast adenocarcinoma) and NCI-H460 (non-small cell lung cancer), using a protocol previously described by Abreu et al. ${ }^{17}$ where the cell growth inhibition was measured at $540 \mathrm{~nm}$ (ELX800 microplate reader, Bio-Tek Instruments, Inc.; Winooski, VT, USA) using the sulforhodamine B assay. For non-tumor porcine liver cells (PLP2) freshly harvested porcine liver was used to obtain the cell culture, designated as PLP2.

The growth inhibition was evaluated using the sulforhodamine B assay and the results were expressed in $\mathrm{GI}_{50}$ values, corresponding to the extract concentration that inhibited 50\% net cell growth. Ellipticine was used as a positive control.

2.3.4. Antimicrobial activity. The microbial strains were clinical isolates donated from patients hospitalized in various departments at the Hospital Center of Trás-os-Montes and Alto Douro (Vila Real, Portugal). Five Gram-negative bacteria (Escherichia coli (isolated from urine), Proteus mirabilis (isolated from wound exudate), Klebsiella pneumoniae (isolated from urine), Pseudomonas aeruginosa (isolated from expectoration) and Morganella morganii (isolated from urine)), and four Gram-positive bacteria (Enterococcus faecalis (isolated from urine), Listeria monocytogenes (isolated from cerebrospinal fluid), methicillin-sensitive Staphylococcus aureus (MSSA) (isolated from wound exudate), and methicillin-resistant Staphylococcus aureus (MRSA) (isolated from expectoration)), and a yeast, Candida albicans (isolated from urine), were tested. All these bacteria were incubated at $37^{\circ} \mathrm{C}$ in an appropriate fresh medium for $24 \mathrm{~h}$ before analysis to maintain the exponential growth phase, except for Candida albicans, which was incubated at room temperature for $48 \mathrm{~h}$.

The MIC determination was conducted using a colorimetric assay according to a procedure previously described by Pires et $a .^{18}$ The MIC values were obtained by adding $40 \mu \mathrm{L}$ of p-iodonitrotetrazolium chloride (INT, $0.2 \mathrm{mg} \mathrm{mL} \mathrm{mL}^{-1}$ ) and further incubation at $37^{\circ} \mathrm{C}$ for $30 \mathrm{~min}$. 
MBC were determined by plating on a solid medium $50 \mu \mathrm{L}$ of the liquid from each well that showed no changes in colour and further incubation at $37^{\circ} \mathrm{C}$ for $24 \mathrm{~h}$.

Three negative controls were prepared (one with MuellerHinton Broth (MHB), another with the extract, and a third with medium and antibiotic). One positive control was prepared with MHB and for each inoculum. For the Gram-negative bacteria, antibiotics, such as ampicillin and imipenem, were used as positive controls, while ampicillin and vancomycin were used for the Gram-positive bacteria, and fluconazole was used for the antifungal activity.

\subsection{Characterization of phenolic compounds by LC-DAD-ESI/MSn}

The ethyl acetate fraction was dissolved in methanol at a concentration of $5 \mathrm{mg} \mathrm{mL} \mathrm{m}^{-1}$ and filtered through a $0.22 \mu \mathrm{m}$ disposable LC filter disk. Chromatographic analysis was performed using a Dionex Ultimate 3000 UPLC (Thermo Scientific, San Jose, CA, USA) system as previously described by Bessada et $a .^{19}$ Double online detection was carried out in a DAD using 280, 330 and $370 \mathrm{~nm}$ as the preferred wavelengths and in a mass spectrometer (MS) operating in negative mode, using a Linear Ion Trap LTQ XL mass spectrometer (Thermo Finnigan, San Jose, CA, USA) equipped with an ESI source. Data acquisition was carried out with an Xcalibur ${ }^{\circledR}$ data system (Thermo Finnigan, San Jose, CA, USA). The phenolic compounds were identified by comparing their retention times, UV-vis and mass spectra with those obtained from standard compounds, when available. Otherwise, compounds were tentatively identified comparing the obtained information with available data reported in the literature. For a quantitative analysis, a calibration curve for each available phenolic standard (catechin, luteolin-6- $C$-glucoside, apigenin-6- $C$-glucoside, quercetin-3-O-glucoside, kampherol-3-O-glucoside, naringen- ina, and apigenina-7-O-glucoside) was constructed based on the UV signal. For the identified phenolic compounds for which a commercial standard was not available, the quantification was performed through the calibration curve of the most similar available standard. The results were expressed as $\mathrm{mg} \mathrm{g}^{-1}$ of the extract.

\subsection{Statistical analysis}

All assays were carried out in triplicate and the results were expressed as the mean values and standard deviation (SD). Analysis was performed through a one-way analysis of variance (ANOVA) followed by a Tukey's HSD test with $p=0.05$, using the SPSS v. 23.0 program (IBM Corp., Armonk, New York, USA).

\section{Results and discussion}

\subsection{Bioactive properties of individual fractions of G. brasiliensis}

The antioxidant activity was assessed using different in vitro methods with each presenting a different mechanism of action. Considering that each extract fraction is composed of different individual compounds, the mechanism by which they exert an antioxidant effect might also differ. The antioxidant activities of the different fractions of $G$. brasiliensis are presented in Table 1. For the DPPH assay, the ethyl acetate fraction $\left(\mathrm{EC}_{50}, 31.2 \pm 0.2 \mu \mathrm{g} \mathrm{mL} \mathrm{m}^{-1}\right)$ was observed to be the most significant, indicating a high antioxidant activity comparable to Trolox. The ferric reducing ability of the samples was similar to those obtained for the DPPH assay, where the ethyl acetate fraction presented the most significant antioxidant capacity $\left(\mathrm{EC}_{50}, 68 \pm 0.2 \mu \mathrm{g} \mathrm{mL}^{-1}\right)$, followed by the dichloromethane fraction $\left(\mathrm{EC}_{50}, 131 \pm 0.2 \mu \mathrm{g} \mathrm{mL}^{-1}\right)$. Similar results were also obtained in the TBARS and $\beta$-carotene bleaching

Table 1 Bioactive properties of $G$. brasiliensis tested with three different extracts

\begin{tabular}{|c|c|c|c|c|}
\hline & Ethyl acetate & Dichloromethane & Hexane & Control \\
\hline \multicolumn{5}{|l|}{ Antioxidant activity $\left(\mathrm{EC}_{50}\right.$ values, $\left.\mu \mathrm{g} \mathrm{mL}^{-1}\right)$} \\
\hline DPPH scavenging activity & $31.2 \pm 0.2^{\mathrm{c}}$ & $60 \pm 2^{b}$ & $516 \pm 13^{\mathrm{a}}$ & $41 \pm 1$ \\
\hline$\beta$-Carotene bleaching inhibition & $15.9 \pm 0.3^{\mathrm{c}}$ & $539 \pm 9^{b}$ & $600 \pm 17^{\mathrm{a}}$ & $18 \pm 1$ \\
\hline Reducing power & $68.8 \pm 0.2^{\mathrm{c}}$ & $131 \pm 1^{\mathrm{b}}$ & $365 \pm 5^{\mathrm{a}}$ & $41.7 \pm 0.3$ \\
\hline TBARS inhibition & $4.6 \pm 0.2^{\mathrm{c}}$ & $23 \pm 1^{b}$ & $45.8 \pm 0.3^{\mathrm{a}}$ & $23 \pm 1$ \\
\hline \multicolumn{5}{|c|}{ Anti-inflammatory activity $\left(\mathrm{EC}_{50}\right.$ values, $\left.\mu \mathrm{g} \mathrm{mL}^{-1}\right)$} \\
\hline Nitric oxide (NO) production & $205 \pm 9^{a}$ & $83 \pm 9^{c}$ & $112 \pm 9^{b}$ & $16 \pm 1$ \\
\hline \multicolumn{5}{|c|}{ Cytotoxicity to tumor cell lines $\left(\mathrm{GI}_{50}\right.$ values, $\left.\mu \mathrm{g} \mathrm{mL}^{-1}\right)$} \\
\hline HeLa (cervical carcinoma) & $253 \pm 1^{\mathrm{a}}$ & $41 \pm 4^{\mathrm{c}}$ & $91 \pm 2^{b}$ & $1.91 \pm 0.06$ \\
\hline HepG2 (hepatocellular carcinoma) & $279 \pm 7^{\mathrm{a}}$ & $57 \pm 2^{c}$ & $102 \pm 5^{\mathrm{b}}$ & $1.1 \pm 0.2$ \\
\hline MCF-7 (breast carcinoma) & $326 \pm 20^{\mathrm{a}}$ & $60 \pm 3^{\mathrm{c}}$ & $148 \pm 8^{\mathrm{b}}$ & $0.91 \pm 0.04$ \\
\hline NCI-H460 (non-small cell lung cancer) & $348 \pm 15^{\mathrm{a}}$ & $72 \pm 4^{\mathrm{c}}$ & $117 \pm 1^{\mathrm{b}}$ & $1.0 \pm 0.1$ \\
\hline \multicolumn{5}{|c|}{ Cytotoxicity to non-tumor cell lines $\left(\mathrm{GI}_{50}\right.$ values, $\left.\mu \mathrm{g} \mathrm{mL}^{-1}\right)$} \\
\hline PLP2 (porcine liver primary culture) & $>400$ & $303 \pm 8$ & $>400$ & $3.2 \pm 0.7$ \\
\hline
\end{tabular}

Trolox, dexamethasone, and ellipticine were used as positive controls in the antioxidant, anti-inflammatory, and cytotoxic assays, respectively. The antioxidant activity was expressed as $\mathrm{EC}_{50}$ values, corresponding to the extract concentration corresponding to $50 \%$ of antioxidant activity or 0.5 of absorbance in the reducing power assay. Results of the anti-inflammatory activity are expressed in $\mathrm{EC}_{50}$ values: the sample concentration providing $50 \%$ of inhibition of nitric oxide $(\mathrm{NO})$ production. Cytotoxicity results are expressed in $\mathrm{GI}_{50}$ values, corresponding to the sample concentration achieving $50 \%$ of growth inhibition in human tumor cell lines or in liver primary culture PLP2. In each row, values for each extract followed by different Latin letters indicate significant differences among the extracts $(p<0.05)$. 
assay with the ethyl acetate fraction presenting the highest antioxidant activity. Significant antioxidant activity of ethanol, hexane, and ethyl acetate extracts obtained from $G$. brasiliensis, prepared by sonication, was reported by Saroni et al. ${ }^{9}$ The authors suggest that these results are due to the contribution of the redox-active bioflavonoid present in the extracts and several studies have also suggested a strong correlation between the antioxidant activity of medicinal plants and their phenolic composition. ${ }^{3,20,21}$

The in vitro anti-inflammatory potential of each extract fraction was evaluated by measuring NO inhibition. The most effective fraction was the dichloromethane fraction $\left(\mathrm{EC}_{50}, 83 \pm\right.$ $\left.9 \mu \mathrm{g} \mathrm{mL} \mathrm{m}^{-1}\right)$, closely followed by the hexane fraction $\left(\mathrm{EC}_{50}\right.$, $\left.112 \pm 9 \mu \mathrm{g} \mathrm{mL}{ }^{-1}\right)$, and lastly by the ethyl acetate extract $\left(\mathrm{EC}_{50}\right.$, $205 \pm 9 \mu \mathrm{g} \mathrm{mL}^{-1}$ ). The ethanolic leaf extract from G. brasiliensis showed significant anti-inflammatory potential, as reported by Santa-Cecília et al. ${ }^{14}$ This activity might also be correlated with its phenolic content, such as fukugiside, fukugetin A, guttiferone A and 7-epiclusianone. A significant contribution of bioactive flavonoids in $G$. brasiliensis in the anti-inflammatory activity was also reported by Castardo et $a{ }^{11}{ }^{11}$ The authors induced edema in vivo and exposed paw tissues to hydroalcoholic extracts of $G$. brasiliensis. Results showed a significant increase in paw edema with the reduction in inflammatory mediator release. Considering that inflammation is a central feature of many pathophysiological conditions, fractions from the crude extract have been able to inhibit the production of the inflammatory mediator (NO) and can be a potential source of biomolecules used to suppress the severity of inflammatory disease.

The cytotoxic activity of each fraction was evaluated in nontumor porcine liver cells (PLP2) and in tumor cell lines (breast carcinoma - MCF-7, non-small cell lung carcinoma NCI-H460, cervical carcinoma - HeLa and hepatocellular carcinoma - HepG2), and the results are presented in Table 1. The ethyl acetate and hexane fraction did not show hepatotoxicity against PLP2 cells up to the maximal tested concentration $\left(\mathrm{GI}_{50}>400 \mu \mathrm{g} \mathrm{mL}^{-1}\right)$. However, the dichloromethane fraction showed hepatotoxicity against this cell line $\left(\mathrm{GI}_{50}, 303 \pm 8\right.$ $\mu \mathrm{g} \mathrm{mL}^{-1}$ ), and this might be due to the antagonistic contribution of some compounds present in the extracts. Regarding the cytotoxic effects in tumor cell lines, the three fractions showed an inhibitory capacity and the dichloromethane fraction was the most effective against all the cell lines evaluated. However, the cytotoxic effect of both ethyl acetate and dichloromethane fractions showed a similar order of effectiveness against the tested cell lines HeLa > HepG2 > MCF-7 > NCI-H460. Regarding the dichloromethane fraction, the results obtained in Table 1 show that the concentration required to achieve $50 \%$ of growth inhibition of PLP2 is about 4 times higher than the concentration required to achieve 50\% of growth inhibition of all the human tumor cell lines tested. Therefore, a dosage of $72 \mu \mathrm{g} \mathrm{mL} \mathrm{m}^{-1}$, which was the highest $\mathrm{GI}_{50}$ value obtained (NCI-H460), could be recommended for further studies, in order to guarantee $50 \%$ of growth inhibition of the above tested human tumor cell lines, without presenting tox- icity effects on non-tumor cells. Benzophenone 7-epiclusianone was isolated from the epicarp of $G$. brasiliensis and tested against glial tumor cell lines (U138MG). ${ }^{22}$ This compound was able to inhibit cell viability and showed $50 \%$ of growth inhibition $(18.52 \pm 0.50 \mu \mathrm{M})$. A cytotoxic advancement was reported by Ionta et $a l .{ }^{23}$ for 7-epiclusianone, showing inhibition of human lung adenocarcinoma cell lines (A549) at $16.13 \pm$ $1.12 \mu \mathrm{M}$ and the authors reported cell arrest in G1/S transition phase and induction of the apoptosis process. However, most of these reports available in the literature were carried out on the fruit of $G$. brasiliensis and to the best of our knowledge, this is the first report showing a promising prospect for cytotoxic compounds present in leaves of this species.

The results on the antimicrobial activity of each extract fraction are presented in Table 2, expressed as MICs (Minimum Inhibitory Concentration, $\mathrm{mg} \mathrm{mL}^{-1}$ ) and $\mathrm{MBC}$ (Minimum Bactericidal Concentration, $\mathrm{mg} \mathrm{mL}^{-1}$ ). Hexane and dichloromethane fractions were not able to demonstrate bactericidal activity up to $20 \mathrm{mg} \mathrm{mL} \mathrm{m}^{-1}$ against all the microorganisms tested, with the exception of the hexane fraction which was able to inhibit MRSA and MSSA. However, the ethyl acetate fraction was able to display a broader spectrum antimicrobial activity against all the tested microorganisms with MIC values between 10 and $20 \mathrm{mg} \mathrm{mL}{ }^{-1}$. A previous research study conducted by Naldoni et al. $^{24}$ reported antimicrobial activity for 7-epiclusianone $\left(1.2 \mu \mathrm{g} \mathrm{mL}{ }^{-1}\right)$ and guttiferone-A $\left(2.4 \mu \mathrm{g} \mathrm{mL}{ }^{-1}\right)$, isolated from the pericarp and seeds of $G$. brasiliensis, against Candida albicans, Staphylococcus aureus, Escherichia coli, and Bacillus cereus. So far, this is the only report on the antimicrobial activity of extracts and/or isolated compounds from the leaves of $G$. brasiliensis. In general, these extracts show high antimicrobial potential against Gram-positive bacteria and might be able to accumulate novel compounds that can be used to control diseases associated with Gram-positive bacteria.

\subsection{Identification of phenolic compounds in the ethyl acetate fraction of $G$. brasiliensis}

The results regarding the phenolic profile obtained by HPLC-DAD-ESI/MSn analysis of the ethyl acetate fraction of G. brasiliensis are shown in Table 3. This phenolic profile (Fig. 1) revealed the presence of twelve phenolic compounds, comprising five bioflavonoids, four flavones, two flavonols and one flavan-3-ol. The identification of the phenolic compounds was performed taking into account previous reports of chemical studies in Garcinia $^{6,25,26}$ and other plant species. ${ }^{27}$

Bioflavonoids were the most abundant compounds present in G. brasiliensis. These compounds are described to be very characteristic of Garcinia species. Compound $9\left([\mathrm{M}-\mathrm{H}]^{-}\right.$at $\mathrm{m} / \mathrm{z} 717)$ was tentatively identified as morelloflavone-7"-O-glucoside by examining its UV spectrum and mass fragmentation, and it was previously described in the ethyl acetate epicarp extract of $G$. brasiliensis. ${ }^{6}$ Compound $8\left([\mathrm{M}-\mathrm{H}]^{-}\right.$at $\left.\mathrm{m} / \mathrm{z} 719\right)$ was identified as biflavonoid 2 a glucoside (GB-2 ${ }^{2}$-glucoside) and it was previously reported to be isolated from the branches, leaves and fruit of Garcinia oblongifolia Champ. ex 


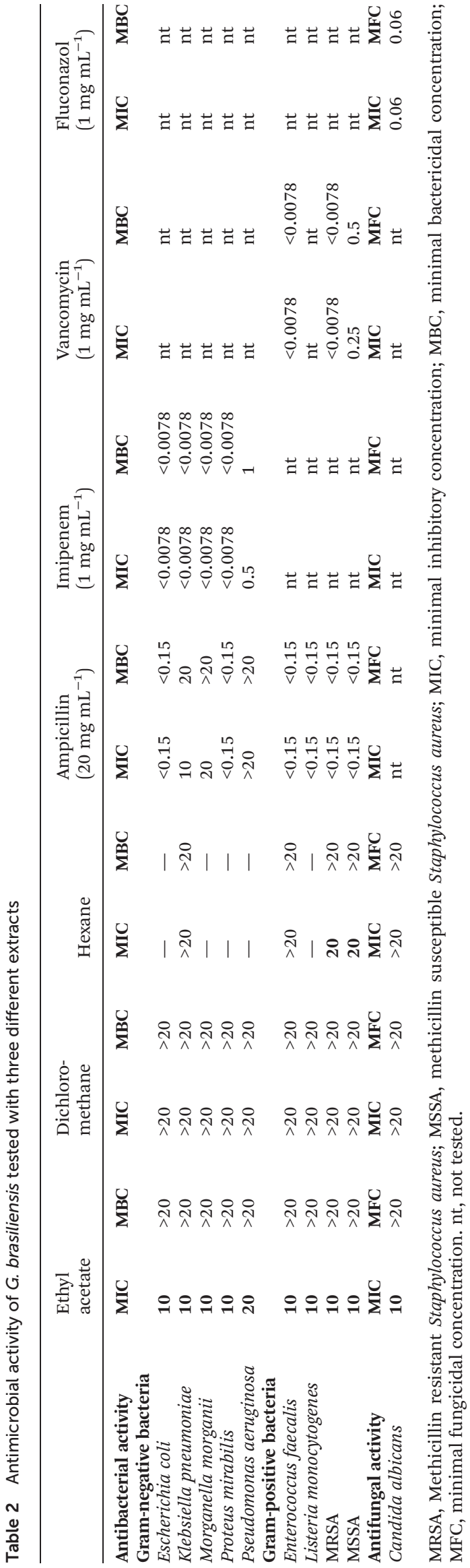

Benth., ${ }^{28}$ ethanol/water seed extract of Garcinia madruno (Kunth) Hammel, ${ }^{29}$ and leaves of Garcinia multiflora Champ. ex Benth. ${ }^{30}$ Both compounds 8 and $\mathbf{9}$ have been previously reported in different Garcinia species, namely Garcinia kola Heckel seed extract, ${ }^{31}$ Garcinia gardneriana (Planch. \& Triana) Zappi leaf extract ${ }^{11}$ and Garcinia griffithii T. Anders. leaf extract. ${ }^{26}$ Due to the consistent presence of these compounds in these species, they are considered to be chemotaxonomic markers for the genus Garcinia. Compound $10\left([\mathrm{M}-\mathrm{H}]^{-}\right.$at $\mathrm{m} / \mathrm{z}$ 703) was identified as binaringenin-7"-O-glucoside, taking into account the findings presented by Salleh et al. ${ }^{26}$ who studied the leaves and stem bark extracts from G. griffithii. Compound $\mathbf{1 1}\left([\mathrm{M}-\mathrm{H}]^{-}\right.$at $\mathrm{m} / \mathrm{z}$ 701) was tentatively identified as volkensiflavone-7"-O-glucoside by examining its UV-VIS spectrum and mass fragmentation and it was previously described in the ethanol/water seed extract of G. madruno. ${ }^{29}$ Compound $12\left([\mathrm{M}-\mathrm{H}]^{-}\right.$at $\left.m / z 555\right)$ was identified as morelloflavone according to its mass and UV-VIS characteristics as previously reported. ${ }^{6}$

Other compounds were identified as $\mathbf{1}$ (catechin), 2 (luteolin-6- $C$-glucoside), 4 (apigenin-8-C-glucoside), 5 (apigenin-6- $C$ glucoside), 6 (quercetin-3-O-glucoside), and 7 (kaempferol-3-Oglucoside). They were unequivocally identified according to their retention time, mass and UV characteristics by comparison with commercial standards. Compound $3\left([\mathrm{M}-\mathrm{H}]^{-}\right.$at $m / z$ $577)$ was identified as apigenin 2 "-O-deoxyhexoside- $C$-hexoside, taking into account the findings described by Ferreres et $a .^{32}$ So far, this is the first report on the presence of these compounds in $G$. brasilienses and both peaks $4(21.2 \pm 0.2$ $\left.\mathrm{mg} \mathrm{g}^{-1}\right)$ and $3\left(19.0 \pm 0.3 \mathrm{mg} \mathrm{g}^{-1}\right)$ were present in high concentrations.

Two bioflavonoids, namely morelloflavone-7"-O-glucoside $\left(52.1 \pm 0.4 \mathrm{mg} \mathrm{g}^{-1}\right)$ and gardinia biflavonoid 2a glucoside $(27.5 \pm$ $0.2 \mathrm{mg} \mathrm{g}^{-1}$ ), were the major compounds among the phenolics, representing $34 \%$ and $18 \%$, respectively, of the phenolic composition.

Some bioflavonoids have been reported in the literature to be bioactives. Castardo et al. ${ }^{11}$ reported the anti-inflammatory effect of hydroalcoholic leaf extracts from G. gardneriana and suggested that it might be attributed to the presence of gardinia biflavonoid $2 \mathrm{a}$ glucoside. The authors also tested the anti-inflammatory activity of the isolated compound and compared it to the one of the extract. Morelloflavone-7"-O-glucoside was isolated from the epicarp of G. brasiliensis and showed a high antioxidant activity using DPPH radical scavenging and reducing power assays $\left(\mathrm{IC}_{50}, 52.4 \pm 7.60\right.$ and $0.250 \pm 0.043 \mu \mathrm{g} \mathrm{mL} \mathrm{mL}^{-1}$, respectively). ${ }^{6}$ DPPH scavenging activity $\left(108.1 \pm 0.9 \mu \mathrm{g} \mathrm{mL} \mathrm{m}^{-1}\right)$ was also reported for morelloflavone- $7^{\prime \prime}-O$-glucoside isolated from the leaves and stem bark of G. griffithii. $^{26}$ Morelloflavone-7"-O-glucoside and morelloflavone were isolated from the root bark of Allanblackia floribunda Oliv. and both the compounds were found to present broad spectrum antimicrobial activity against Gram-positive and Gramnegative bacteria and fungi with MICs values between 19.53 and $312.5 \mu \mathrm{g} \mathrm{mL}{ }^{-133}$ 
Table 3 Retention time $\left(R_{\mathrm{t}}\right)$ wavelengths of maximum absorption in the visible region $\left(\lambda_{\text {max }}\right)$, mass spectral data, tentative identification and quantification of phenolic compounds in an ethyl acetate extract of the leaves of $G$. brasiliensis

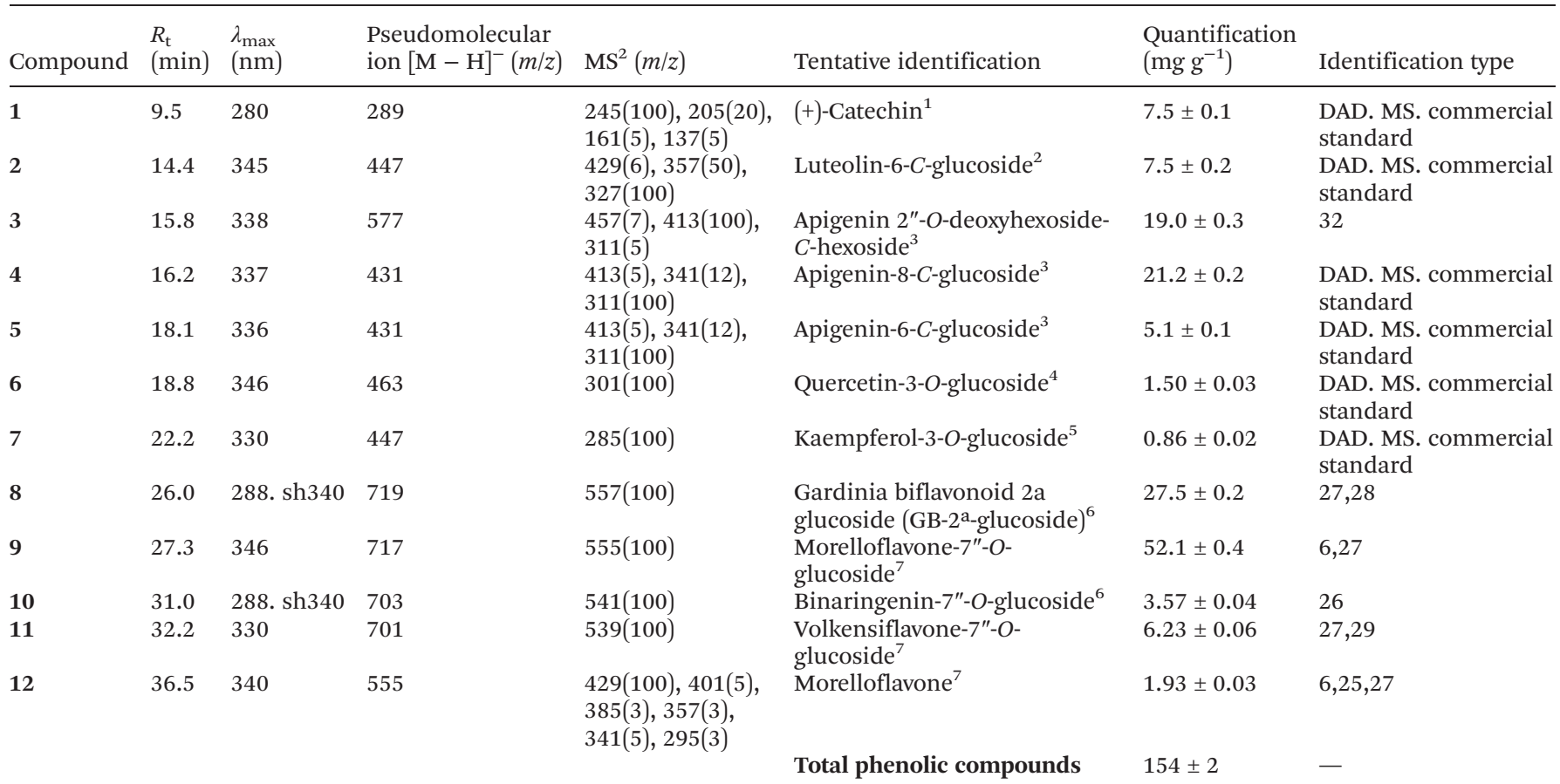

Calibration curves used - 1: catechin $\left(y=84950 x-23200 ; R^{2}=0.999\right) ; 2$ : luteolin-6-C-glucoside $\left(y=4087.1 x+72589 ; R^{2}=0.999\right) ; 3$ : apigenin-6$C$-glucoside $\left(y=4087.1 x+72589 ; R^{2}=0.999\right) ; 4$ : quercetin-3-O-glucoside $\left(y=34843 x-160173 ; R^{2}=0.999\right) ; 5$ : kampherol-3-O-glucoside $(y=$ $\left.11117 x+30861 ; R^{2}=0.999\right) ; 6$ : naringenina $\left(y=18433 x+78903 ; R^{2}=0.999\right) ; 7$ : apigenina-7-O-glucoside $\left(y=10683 x-45794 ; R^{2}=0.996\right)$.

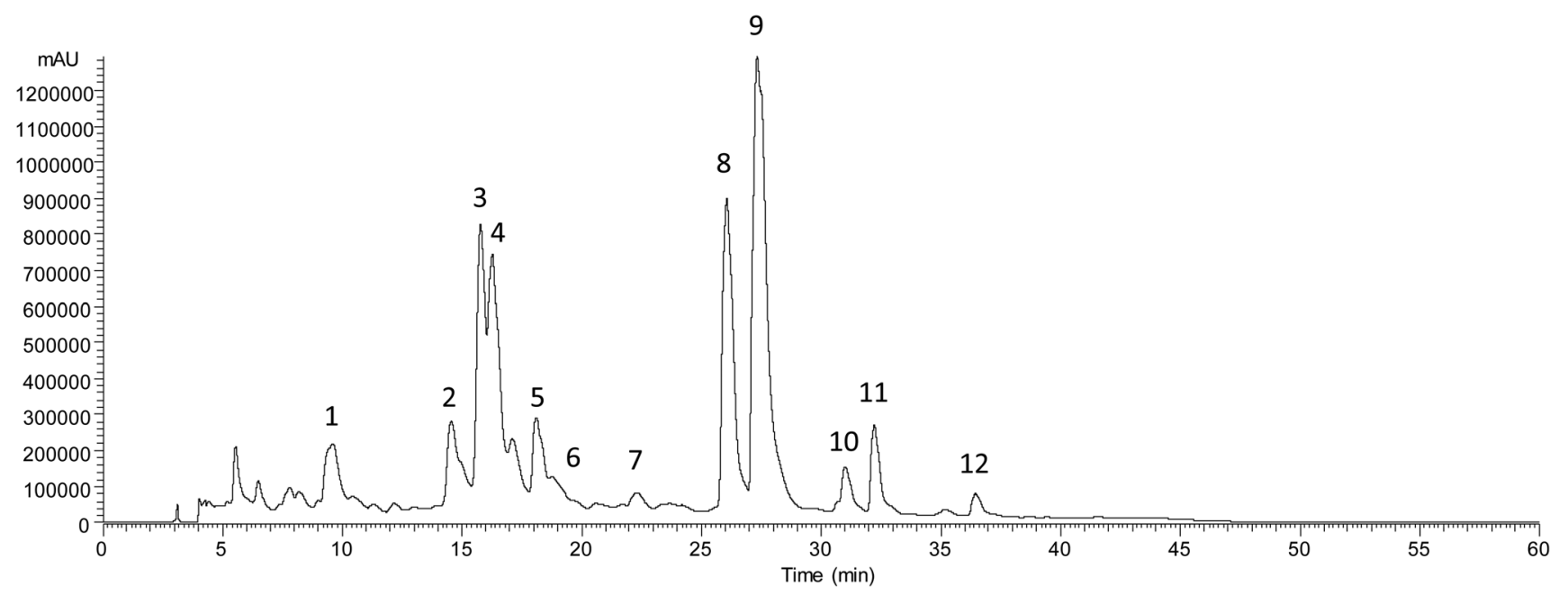

Fig. 1 Phenolic profile of a G. brasiliensis ethyl acetate extract recorded at $280 \mathrm{~nm}$.

Therefore, the interesting bioactive properties presented in the present work may be due to the contribution of these compounds, hence there is a need to conduct more comprehensive studies related to these individual compounds in order to enhance their exploration in pharmaceutical and medicinal chemistry.

\section{Conclusion}

Garcinia brasiliensis is an interesting medicinal plant native to the Amazon region which is primarily cultivated for its fruits. However, several medicinal effects have been attributed to its various plant parts because of the significant amount of bio- 
active molecules. The results of the present work reveal that the different fractions obtained from the crude methanolic extract possess antioxidant capacity, being more pronounced in the ethyl acetate fraction. The dichloromethane fraction was more efficient in the anti-inflammatory and cytotoxic activities. For the antimicrobial assay, the ethyl acetate fraction revealed broad spectrum microbial inhibition against Gram-negative and Gram-positive bacteria and the fungus Candida albicans. The phenolic profile of the ethyl acetate fraction was achieved by HPLC-DAD-ESI/MSn analysis and this fraction revealed itself as the most promising among others for all the activities tested. In this fraction, 12 flavonoid compounds were identified and morelloflavone-7"-O-glucoside and gardinia biflavonoid 2 a glucoside were the most abundant. This work shows that the leaves of $G$. brasiliensis are an attractive source of bioactive molecules with interesting health-promoting benefits, suitable to be explored for pharmaceutical, food and even cosmeceutical applications.

\section{Conflicts of interest}

No conflict of interest.

\section{Acknowledgements}

The authors are grateful to the Foundation for Science and Technology (FCT, Portugal) and FEDER under Programme PT2020 for financial support to CIMO (UID/AGR/00690/2013) and L. Barros's contract; to the FEDER-Interreg EspañaPortugal programme for financial support through the project 0377_Iberphenol_6_E.

\section{References}

1 M. Carocho and I. C. F. R. Ferreira, A review on antioxidants, prooxidants and related controversy: Natural and synthetic compounds, screening and analysis methodologies and future perspectives, Food Chem. Toxicol., 2013, $51,15-25$.

2 O. Taofiq, A. M. González-paramás, M. F. Barreiro and I. C. F. R. Ferreira, Hydroxycinnamic Acids and Their Derivatives: Cosmeceutical Significance, Challenges and Future Perspectives, a Review, Molecules, 2017, 22, 1-24.

3 S. Senio, C. Pereira, J. Vaz, M. Sokovic, L. Barros and I. C. F. R. Ferreira, Dehydration process influences the phenolic profile, antioxidant and antimicrobial properties of Galium aparine L., Ind. Crops Prod., 2018, 120, 97-103.

4 I. G. C. Bieski, M. Leonti, J. T. Arnason, J. Ferrier, M. Rapinski, I. M. P. Violante, S. O. Balogun, J. F. C. A. Pereira, R. C. F. Figueiredo, C. R. A. S. Lopes, D. R. Da Silva, A. Pacini, U. P. Albuquerque and D. T. De Oliveira Martins, Ethnobotanical study of medicinal plants by population of Valley of Juruena Region, Legal Amazon, Mato Grosso, J. Ethnopharmacol., 2015, 173, 383-423.
5 L. de C. Brito, A. L. R. Berenger and M. R. Figueiredo, An overview of anticancer activity of Garcinia and Hypericum, Food Chem. Toxicol., 2017, 109, 847-862.

6 V. S. Gontijo, T. C. De Souza, I. A. Rosa, M. G. Soares, M. A. Da Silva, W. Vilegas, C. Viegas and M. H. Dos Santos, Isolation and evaluation of the antioxidant activity of phenolic constituents of the Garcinia brasiliensis epicarp, Food Chem., 2012, 132, 1230-1235.

7 L. P. Coelho, M. F. Serra, A. L. de Aguiar Pires, R. S. B. Cordeiro, P. M. R. e Silva, M. H. dos Santos and M. A. Martins, 7-Epiclusianone, a Tetraprenylated Benzophenone, Relaxes Airway Smooth Muscle through Activation of the Nitric Oxide-cGMP Pathway, J. Pharmacol. Exp. Ther., 2008, 327, 206-214.

8 P. B. M. C. Derogis, F. T. Martins, T. C. De Souza, M. E. C. De Moreira, J. D. Souza Filho, A. C. Doriguetto, K. R. D. De Souza, M. P. Veloso and M. H. Dos Santos, Complete assignment of the1H and13C NMR spectra of garciniaphenone and keto-enol equilibrium statements for prenylated benzophenones, Magn. Reson. Chem., 2008, 46, 278-282.

9 P. Saroni Arwa, M. L. Zeraik, V. Farias Ximenes, L. M. Da Fonseca, V. Da Silva Bolzani and D. H. Siqueira Silva, Redox-active biflavonoids from Garcinia brasiliensis as inhibitors of neutrophil oxidative burst and human erythrocyte membrane damage, J. Ethnopharmacol., 2015, 174, 410-418.

10 M. E. de C. Moreira, D. I. G. Natal, R. C. L. Toledo, N. M. Ramirez, S. M. R. Ribeiro, L. dos A. Benjamin, L. L. de Oliveira, D. A. Rodrigues, J. D. Antônio, M. P. Veloso, M. H. Dos Santos and H. S. D. Martino, Bacupari peel extracts (Garcinia brasiliensis) reduce high-fat diet-induced obesity in rats, J. Funct. Foods, 2017, 29, 143153.

11 J. C. Castardo, A. S. Prudente, J. Ferreira, C. L. Guimarães, F. D. Monache, V. C. Filho, M. F. Otuki and D. A. Cabrini, Anti-inflammatory effects of hydroalcoholic extract and two biflavonoids from Garcinia gardneriana leaves in mouse paw oedema, J. Ethnopharmacol., 2008, 118, 405-411.

12 S. A. Figueiredo, F. M. P. Vilela, C. A. Da Silva, T. M. Cunha, M. H. Dos Santos and M. J. V. Fonseca, In vitro and in vivo photoprotective/photochemopreventive potential of Garcinia brasiliensis epicarp extract, J. Photochem. Photobiol., B, 2014, 131, 65-73.

13 I. O. Pereira, M. J. Marques, A. L. R. Pavan, B. S. Codonho, C. L. Barbiéri, L. A. Beijo, A. C. Doriguetto, D. D. M. Costa and M. H. dos Santos, Leishmanicidal activity of benzophenones and extracts from Garcinia brasiliensis Mart. fruits, Phytomedicine, 2010, 17, 339-345.

14 F. V. Santa-Cecília, F. C. Vilela, C. Q. Da Rocha, D. F. Dias, G. P. Cavalcante, L. A. S. Freitas, M. H. Dos Santos and A. Giusti-Paiva, Anti-inflammatory and antinociceptive effects of Garcinia brasiliensis, J. Ethnopharmacol., 2011, 133, 467-473.

15 S. A. Petropoulos, C. Pereira, N. Tzortzakis, L. Barros and I. C. F. R. Ferreira, Nutritional Value and Bioactive 
Compounds Characterization of Plant Parts from Cynara cardunculus L. (Asteraceae) Cultivated in Central Greece, Front. Plant Sci., 2018, 9, 1-12.

16 O. Taofiq, R. C. Calhelha, S. Heleno, L. Barros, A. Martins, C. Santos-Buelga, M. J. R. P. Queiroz and I. C. F. R. Ferreira, The contribution of phenolic acids to the anti-inflammatory activity of mushrooms: Screening in phenolic extracts, individual parent molecules and synthesized glucuronated and methylated derivatives, Food Res. Int., 2015, 76, 821-827.

17 R. M. V. Abreu, I. C. F. R. Ferreira, R. C. Calhelha, R. T. Lima, M. H. Vasconcelos, F. Adega, R. Chaves and M. J. R. P. Queiroz, Anti-hepatocellular carcinoma activity using human HepG2 cells and hepatotoxicity of 6-substituted methyl 3-aminothieno[3,2- $b]$ pyridine-2- carboxylate derivatives: In vitro evaluation, cell cycle analysis and QSAR studies, Eur. J. Med. Chem., 2011, 46, 5800-5806.

18 T. C. S. P. Pires, M. I. Dias, L. Barros, M. J. Alves, M. B. P. P. Oliveira, C. Santos-Buelga and I. C. F. R. Ferreira, Antioxidant and antimicrobial properties of dried Portuguese apple variety (Malus domestica Borkh. cv Bravo de Esmolfe), Food Chem., 2018, 240, 701-706.

19 S. M. F. Bessada, J. C. M. Barreira, L. Barros, I. C. F. R. Ferreira and M. B. P. P. Oliveira, Phenolic profile and antioxidant activity of Coleostephus myconis (L.) Rchb.f.: An underexploited and highly disseminated species, Ind. Crops Prod., 2016, 89, 45-51.

20 R. Guimarães, L. Barros, M. Dueñas, A. M. Carvalho, M. J. R. P. Queiroz, C. Santos-Buelga and I. C. F. R. Ferreira, Characterisation of phenolic compounds in wild fruits from Northeastern Portugal, Food Chem., 2013, 141, 3721-3730.

21 C. Pereira, L. Barros, M. J. Alves, L. Pereira, C. SantosBuelga and I. C. F. R. Ferreira, Phenolic profile and antimicrobial activity of different dietary supplements based on Cochlospermum angolensis Welw, Ind. Crops Prod., 2015, 74, 412-416.

22 L. Sales, J. A. Pezuk, K. S. Borges, M. Sol Brassesco, C. A. Scrideli, L. G. Tone, M. H. dos Santos, M. Ionta and J. C. de Oliveira, Anticancer activity of 7-epiclusianone,a benzophenone from Garcinia brasiliensis, in glioblastoma, BMC Complementary Altern. Med., 2015, 15, 1-8.

23 M. Ionta, G. A. Ferreira-Silva, E. L. Niero, E. D. M. Costa, A. A. Martens, W. Rosa, M. G. Soares, G. M. MachadoSantelli, J. H. G. Lago and M. H. Santos, 7-Epiclusianone, a benzophenone extracted from Garcinia brasiliensis (Clusiaceae), induces cell cycle arrest in G1/S transition in A549 cells, Molecules, 2015, 20, 12804-12816.

24 F. J. Naldoni, A. L. R. Claudino, J. W. Cruz, J. K. Chavasco, P. M. F. e Silva, M. P. Veloso and M. H. Dos Santos,
Antimicrobial Activity of Benzophenones and Extracts from the Fruits of Garcinia brasiliensis, J. Med. Food, 2009, 12, 403-407.

25 V. S. Gontijo, W. A. S. Judice, B. Codonho, I. O. Pereira, D. M. Assis, J. P. Januário, E. E. Caroselli, M. A. Juliano, A. De Carvalho Dosatti, M. J. Marques, C. V. Junior and M. H. Dos Santos, Leishmanicidal, antiproteolytic and antioxidant evaluation of natural biflavonoids isolated from Garcinia brasiliensis and their semisynthetic derivatives, Eur. J. Med. Chem., 2012, 58, 613-623.

26 W. M. N. H. W. Salleh, N. S. A. N. Sazali, F. Ahmad and M. Taher, Biflavonoids from the leaves and stem bark of Garcinia griffithii and their biological activities, Marmara Pharm. J., 2017, 21, 889-897.

27 G. A. Akpanika, A. Winters, T. Wilson, G. A. Ayoola, A. A. Adepoju-Bello and B. Hauck, Polyphenols from Allanblackia floribunda seeds: Identification, quantification and antioxidant activity, Food Chem., 2017, 222, 35-42.

28 P. Li, H. AnandhiSenthilkumar, S. biao Wu, B. Liu, Z. yong Guo, J. E. Fata, E. J. Kennelly and C. lin Long, Comparative UPLC-QTOF-MS-based metabolomics and bioactivities analyses of Garcinia oblongifolia, J. Chromatogr. B: Anal. Technol. Biomed. Life Sci., 2016, 1011, 179-195.

29 L. Carrillo-Hormaza, A. M. Ramírez, C. Quintero-Ortiz, M. Cossio, S. Medina, F. Ferreres, A. Gil-Izquierdo and E. Osorio, Comprehensive characterization and antioxidant activities of the main biflavonoids of Garcinia madruno: A novel tropical species for developing functional products, J. Funct. Foods, 2016, 27, 503-516.

30 Y. M. Lin, H. Anderson, M. T. Flavin, Y. H. S. Pai, E. MataGreenwood, T. Pengsuparp, J. M. Pezzuto, R. F. Schinazi, S. H. Hughes and F. C. Chen, In vitro anti-HIV activity of biflavonoids isolated from Rhus succedanea and Garcinia multiflora, J. Nat. Prod., 1997, 60, 884-888.

31 O. R. Ayepola, M. E. Cerf, N. L. Brooks and O. O. Oguntibeju, Kolaviron, a biflavonoid complex of Garcinia kola seeds modulates apoptosis by suppressing oxidative stress and inflammation in diabetes-induced nephrotoxic rats, Phytomedicine, 2014, 21, 1785-1793.

32 F. Ferreres, A. Gil-Izquierdo, P. B. Andrade, P. Valentão and F. A. Tomás-Barberán, Characterization of $C$-glycosyl flavones $O$-glycosylated by liquid chromatography-tandem mass spectrometry, J. Chromatogr. A, 2007, 1161, 214-223.

33 V. Kuete, A. G. B. Azebaze, A. T. Mbaveng, E. L. Nguemfo, E. T. Tshikalange, P. Chalard and A. E. Nkengfack, Antioxidant, antitumor and antimicrobial activities of the crude extract and compounds of the root bark of Allanblackia floribunda, Pharm. Biol., 2011, 49, 57-65. 